\title{
Ex-Head of State Immunity: A Proposed Statutory Tool of Foreign Policy
}

\author{
Peter Evan Bass
}

American courts recently have become fora for a new type of transnational litigation. Deposed leaders of foreign states, who have fled their countries with American assistance or who have been invited into the United States, have been pursued in state and federal courts by plaintiffs to recoup allegedly ill-gotten gains. These plaintiffs may handicap future American efforts to effect peaceful transitions of power in nations deemed vital to the United States. Heads of state ${ }^{1}$ seeking escape from internal political upheaval may grow reluctant to accept an American offer of safe refuge, knowing that the American judicial system may expose them to extensive and relentless litigation.

This Note proposes a statute-based doctrine of immunity which, under certain circumstances, could protect from suit in American courts ex-heads of state who are escorted or invited into an American jurisdiction. Section

1. Modern American case law, see infra note 10 , and scholarly writing, see infra note 2 , do not define "head of state." However, the rough contours of the term may be discerned from a survey of an admittedly limited supply of positive law and precedent. One multilateral anti-terrorism convention to which the United States is a party defines "head of state" as "any member of a collegial body performing the functions of Head of State under the constitution of the State concerned, a Head of Government or a Minister for Foreign Affairs . . . as well as members of his family who accompany him." Convention on the Prevention and Punishment of Crimes Against Internationally Protected Persons Including Diplomatic Agents, Dec. 14, 1973, 28 U.S.T. 1975, T.I.A.S. No. 8532.

American courts have granted head of state immunity to two heads of government, a foreign minister, the King of Saudi Arabia, the Pope, and the Prince of Wales, the latter two classified as heads of state under the unwritten constitutions of their respective states. For further discussion of these cases, see infra note 10 .

While American courts have not set well-defined limits on the kinds of officials that may enjoy head of state immunity, one recent decision addresses this issue. Republic of the Phil. v. Marcos, No. 86146, slip op. (N.D. Cal. Feb. 11, 1987). In Marcos, the district court ruled that head of state immunity did not reach the Solicitor General of the Philippines, on whom former Philippines President Ferdinand Marcos attempted to serve a subpoena in connection with ongoing litigation in federal district court in Hawaii. For a discussion of this and other cases involving Marcos, see infra note 25. 
I examines current immunity doctrine, describes recent developments in transnational litigation that suggest the need to expand current doctrine to encompass ex-head of state immunity and assesses the policy interests served or sacrificed by offering former heads of state a shield against suit in American courts. Section II argues that the President is the proper authority to exercise this new foreign policy tool and that a statutory framework would be the best means for delineating the boundaries of this authority. Section III suggests a limited scope for the proposed ex-head of state immunity: Congress should permit the President to grant immunity for acts that fall short of internationally-recognized human rights violations.

\section{Head of State Immunity}

\section{A. Current Doctrine}

The traditional doctrine of head of state immunity ${ }^{2}$ stems largely from early notions of sovereign immunity, which considered the state and its leader to be one indivisible entity. ${ }^{3}$ Up until the middle of this century, a de jure doctrine of absolute immunity extended to foreign states and their leaders in American courts. ${ }^{4}$ The doctrine of absolute sovereign immunity was formally supplanted by a restrictive immunity doctrine in 1952, when the State Department announced it would suggest immunity for states performing public acts and withhold this suggestion for private acts. ${ }^{5}$ State

2. For a thorough examination of the scope of traditional head of state immunity, see Note, Resolving the Confusion over Head of State Immunity: The Defined Rights of Kings, 86 CoLum. L. REV. 169, 170-71 (1986).

3. See Restatement (Second) of Foreign Relations Law $\$ 66$ (1965) ("The immunity of a foreign state under the rule stated in section 65 extends to . . . its head of state"); see also Note, supra note 2, at 170 n.10. However, the new Third Restatement contains more ambiguous language which suggests that sovereign and head of state immunity are no longer coextensive. ResTATEMENT (THIRD) OF FOREIGN RELATIONS LAW $\S 464$ reporters' note 14 (Final Draft 1987) [hereinafter ThIRD RESTATEMENT] ("Ordinarily, a proceeding against a head of state or government that is in essence a suit against the state is treated like a claim against the state for purposes of immunity."). This language reflects the disjunction in courts' treatment of heads of state and states themselves since the passage in 1976 of the Foreign Sovereign Immunitics Act, 22 U.S.C. $\$ \S 1330,1602-1611$ (1982). That Act codified the law of sovereign immunity, but left head of state immunity still governed by the rule of executive suggestion. See Note, supra note 2, at 169-76; infra notes 4-11 and accompanying text.

4. In Schooner Exchange v. McFaddon, 11 U.S. (7 Cranch) 116 (1812), the seminal case on American sovereign immunity doctrine, Chief Justice Marshall argued that the "perfect equality and absolute independence of sovereigns" compelled a finding of absolute immunity. Id. at 137. Later, in Ex parte Peru, 318 U.S. 578 (1943), Chief Justice Stone justified continued adherence to the theory, asserting that absolute immunity avoids the specter of domestic courts sitting in judgment on the acts of other powers and thus "embarrass[ing] the executive arm of the Government in conducting foreign relations." Id. at 588 .

5. Letter from Jack B. Tate, Acting Legal Adviser of the U.S. Dep't of State, to Acting Attorney General Philip B. Perlman (May 19, 1952), reprinted in 26 DeP'T St. Bull. No. 678, at 984-85 (1952). The Tate Letter was a clear signal to foreign states that they would no longer enjoy blanket protection in American courts. See Note, supra note 2, at 173. This determination came in light of the growing tendency of foreign courts to apply a restrictive theory of immunity to U.S. sovereign entities; see also H.R. REP. No. 1487, 94th Cong., 2d Sess. 7 (recounting history of Tate Letter), reprinted in 1976 U.S. Code Cong. \& Admin. NEws 6604, 6605 [hereinafter House REPORT]. 
Department suggestions ${ }^{6}$ were dispositive until the passage of the Foreign Sovereign Immunities Act of 1976 (FSIA), ${ }^{7}$ which codified specific exceptions to foreign sovereign immunity. ${ }^{8}$

Since the enactment of the FSIA, immunity for foreign states as entities and immunity for heads of state as individuals have been decided through different procedures and at the initiative of different branches of the federal government. ${ }^{\circ}$ The FSIA, by definition, converts foreign sovereign immunity determinations into questions of statutory interpretation: Congress has entrusted the courts with sole authority to recognize immunity. Head of state cases, on the other hand, continue to be decided through the method of dispositive executive suggestion. ${ }^{10}$ Thus, despite the historical conflation of head of state and sovereign immunity, contemporary Ameri-

6. In general, executive suggestions of immunity are expressed through written communications to the court by the State Department's Legal Adviser. These communications are submitted by the Justice Department as the sole representative of the federal government in United States courts. 28 U.S.C. \$516 (1982). Private litigants may request that the Legal Adviser draft a letter to the court, though nothing prevents the court itself from requesting advice from the Legal Adviser. For a general description of the practice of executive suggestion, see Lowenfeld, Act of State and Department of State, 66 AM. J. INT'L L. 795 (1972).

7. 28 U.S.C. $\S \S 1330,1602-1611$ (1982).

8. 28 U.S.C. $\$ 1605$ (1982) (detailing exceptions involving waiver, commercial activity, property taken in violation of international law, immovable property within U.S., and non-commercial torts in U.S.).

9. A number of foreign states have recently passed sovereign immunity statutes that also address head of state immunity. Those statutes consider head of state immunity in the same terms as diplomatic immunity. None of the statutes deals explicitly with the immunity of former heads of state. See, e.g., State Immunity Act, 1978, ch. 33, reprinted in 17 I.L.M. 1123, 1128-29 (1978) (United Kingdom); State Immunity Act, 1982, ch. 95, 1980-1983 Can. Stat. 2949, reprinted in 21 I.L.M. 798, 801 (1982) (Canada).

10. Head of state immunity has been invoked only seven times since 1952 . In the three cases decided after the enactment of the FSIA in 1976, the court did not consult the statute but adhered to the suggestion of the State Department. Head of state immunity has paralleled the trend toward restrictive immunity for sovereign states. See In re Wilson, No. 84-01415-A (Bankr. E.D. Va. filed Aug. 5, 1987) (suggestion to immunize President Hosni Mubarak from suit by debtor); Republic of the Phil. v. Marcos, No. 86-146, slip op. (N.D. Cal. Feb. 11, 1987) (head of state immunity did not reach Solicitor General of Philippines, but State Department suggestion deemed inartful grant of diplomatic immunity); Domingo v. Marcos, No. C82-1055-V, slip op. (W.D. Wash. Dec. 23, 1982) (suit for damages against then-President Marcos, charging acts of political assassination, dismissed following suggestion of immunity); O'Hair v. Wojtyla (D.D.C. 1979), reported in 1979 Dig. U.S. PrAC. INT'L L. 897 (injunction against Pope sought to prevent celebration of mass; dismissed pursuant to department suggestion and on other grounds); Kilroy v. Windsor (Charles, Prince of Wales) (N.D. Ohio 1978), reported in 1978 Dig. U.S. PRAC. INT'L L. 641 (suit claiming deprivation of constitutional rights following citizen's removal at public ceremony; dismissed following State Department suggestion of immunity.); Psinakis v. Marcos (N.D. Cal. 1975), reported in 1975 DiG. U.S. PrAC. INT'L L. 344 (libel action against then-President Marcos dismissed following State Department's suggestion of immunity); Kendall v. Saudi Arabia (S.D.N.Y. 1965), reported in 1977 Dig. U.S. PraC. INT'L L. 1017, 1053-54 (appendix) (attachment of King Faisal's assets in New York in connection with tort action concerning attack by king's militiamen; dismissed following suggestion of immunity); Chong Boon Kim v. Kim Yong Shik (Haw. Cir. Ct. Sept. 9, 1963), summarized in 58 AM. J. INT'L. L. 186-87 (1964) (suggestion of head of state immunity for foreign minister; dismissed for lack of jurisdiction).

Although there is no uniform standard guiding current determinations of head of state immunity, the State Department has drawn on principles ranging from customary international law to diplomatic immunity. See Note, supra note 2 , at 175-76 \& nn.26-30. For a useful discussion of the arguments in favor of codifying the law of head of state immunity, see Note, supra note 2, at 187-97. 
can practice treats nation-states and individual leaders as distinct juridical entities. ${ }^{11}$

Heads of state enjoy diplomatic immunity ${ }^{12}$ when they perform ceremonial and diplomatic functions within the United States. ${ }^{13}$ However, head of state immunity and diplomatic immunity must be considered distinct concepts. Heads of state exercise broader authority than do diplomats, and diplomatic immunity has been invoked only when the head of state takes the place of his emissaries. ${ }^{14}$

11. Legislative history of the FSIA and the treatment accorded heads of state in the post-FSIA cra both suggest that heads of state were not meant to be covered by that statute. Section 1603 reads:

For the purpose of this chapter-

(a) A "foreign state," except as used in section 1608 of this title [regarding service of process], includes a political subdivision of a foreign state or an agency or instrumentality of a foreign state as defined in subsection (b).

(b) An "agency or instrumentality of a foreign state" means any entity -

(1) which is a separate legal person, corporate or otherwise, and

(2) which is an organ of a foreign state or political subdivision thereof, or a majority of whose shares or other ownership interest is owned by a foreign state or political subdivision thereof, and

(3) which is neither a citizen of a State of the United States as defined in section

1332 (c) and (d) of this title, nor created under the laws of any third country.

28 U.S.C. § 1603 (1982).

While the legislative history does not address head of state immunity explicitly, the thrust of the House Report language indicates that the FSIA was probably meant to target state governments and state-controlled commercial enterprises, rather than individuals. The legislative history states that the phrase "separate legal person" in subsection (b) includes:

[A] corporation, association, foundation, or any other entity which, under the law of the foreign state where it was created, can sue or be sued in its own name, contract in its own name or hold property in its own name . . . . As a general matter, entities which meet the definition of an 'agency or instrumentality of a foreign state' could assume a variety of forms, including a state trading corporation, a mining enterprise, a transport organization such as a shipping line or airline, a steel company, a central bank ....

House REPORT, supra note 5, at 6614. The report also states that an entity which falls outside the definition of "foreign state" or "agency or instrumentality of a foreign state" would not be entitled to sovereign immunity. $I d$.

12. Under the Diplomatic Relations Act, 22 U.S.C. $\S 254 c$ (1982 \& Supp. 1986), the President has the power to specify privileges and immunities for individual members of the diplomatic corps, their families, and diplomatic couriers and also may deviate from the privileges accorded them under the Vienna Convention on Diplomatic Relations, Apr. 18, 1961, 23 U.S.T. 3227, T.I.A.S. No. 7502, 500 U.N.T.S. 95. [hereinafter Diplomatic Convention].

13. See Note, supra note 2, at 170 n.10 (citing 1975 Dig. U.S. PrAc. INT'L L. 345 n.1). The United States is a party to the two major multilateral treaties delineating the scope of diplomatic immunity. See Diplomatic Convention, supra note 12; Vienna Convention on Consular Relations, Apr. 24, 1963, 21 U.S.T. 77, T.I.A.S. No. 6820, 596 U.N.T.S. 261.

Contemporary American foreign relations law treats heads of state as the functional equivalent of diplomats when the former perform functions normally exercised by the latter: "[A] person is authorized to represent a state for purposes of concluding an international agreement if (a) he produces full powers or (b) such authority may clearly be implied in the circumstances." THIRD RESTATEMENT, supra note $3, \S 311(2)$. The Restatement notes that this language is based on the Diplomatic Convention, supra note 12, art. 7(1). ThIRD RestaTEMENT, supra note $3, \S 311$ source note.

14. See Note, supra note 2, at 170-71. Diplomats may claim the protection of the Diplomatic Convention, supra note 12, under American law. Diplomatic Relations Act, 22 U.S.C. § 254(a)-(c) (1982 \& Supp. 1986). That claim will be an absolute bar to liability. See, e.g., Trost v. Tompkins, 44 A.2d 226, 227 (D.C. 1945). On the other hand, heads of state, on those rare occasions that they have been haled into court, have not relied on diplomatic protections but rather on formal State Department suggestions to the court in order to escape liability. See supra note 10. 


\section{B. Recent Transnational Litigation Against Ex-Heads of State}

American courts' application of head of state immunity has been consistent with international law and has been triggered as a result of executive suggestion. ${ }^{16}$ However, while heads of state have enjoyed immunity in American courts, ex-heads of state cannot be assured of similar treatment. Although in principle executive suggestion might be similarly applied to ex-heads of state, ${ }^{18}$ in practice the courts have fashioned ex-head of state doctrine without the participation of the executive branch. Furthermore, there is little international consensus regarding the legal contours of exhead of state immunity. Consequently, authority on ex-head of state doctrine continues to lack coherence.

The Third Restatement suggests that ex-heads of state are usually immune from suit concerning official acts, but still may be haled into foreign court. ${ }^{17}$ Other authority, however, suggests that ex-heads of state enjoy no immunity as a matter of customary international law. ${ }^{18}$ The Second Circuit has suggested that ex-head of state immunity does not extend to private acts. ${ }^{19}$ The Fourth Circuit has held that a successor government may waive whatever immunity a former head of state might claim. ${ }^{20}$ Both the

\footnotetext{
15. See supra notes $1 \& 10$.

16. See infra Section II-B.

17. The Third Restatement distinguishes between the right of states to exercise prescriptive jurisdiction (the right to legislate with respect to certain acts) and adjudicative jurisdiction (the right to subject a party to the state's judicial system). See ThIRD RESTATEMENT, supra note $3, \S 401$.

In section 464, the Third Restatement asserts that states usually may not prescribe, and thus may not adjudicate, with respect to official acts-if a state cannot prescribe, there can be no cause of action under which a plaintiff could sue a head of state. However, states may adjudicate (and thus, must be able to prescribe) with respect to other acts:

Former heads of state or government have sometimes sought immunity from suit in respect of claims arising out of their official acts while in office. Ordinarily, such acts are not within the jurisdiction to prescribe of other states. . . . However, a former head of state appears to have no immunity from jurisdiction to adjudicate.
}

ThIRD Restatement, supra note $3, \S 464$ reporters' note 14 . For an examination of what kinds of official and non-official acts should not benefit from the shield of immunity, see infra Section III.

While states may prescribe and adjudicate with respect to certain categories of acts committed by ex-heads of state, the Third Restatement suggests that even this prerogative may be trumped by executive suggestion: "In the United States, the courts might grant immunity [for ex-heads of state] if suggested by the Executive Branch on foreign policy grounds, even though it is not required by international law." ThiRd Restatement, supra note 3, \& 464 reporters' note 14.

18. S. Sucharitkul, State Immunities and Trading Activities in International Law 27-28 (1959) ("[U]pon the cessation of their public functions sovereigns and diplomats are no longer entitled to any jurisdictional immunity."); see also id. at 32-34, 47-50.

French law endorses this view. See Ex-King Farouk of Egypt v. Christian Dior, S.A.R.L., 84 Clunet 717 (Cour d'appel, Paris 1957), reported in 24 I.L.R. 228 (1957) (after abdication, King Farouk no longer immune from French courts' exercise of jurisdiction). But see Hatch v. Baez, 14 N.Y. Sup. Ct. 596 (1876) (former President of the Dominican Republic entitled to immunity for official acts performed while in office).

19. Republic of the Phil. v. Marcos, 806 F.2d 344, 360 (2d Cir. 1986) (granting preliminary injunction blocking sale of property allegedly owned by Ferdinand and Imelda Marcos); see infra note 21 for passages from the opinion.

20. United States v. (Under Seal) (In re Grand Jury Proceedings: John Doe No. 700), 817 F.2d 1108, 1110-11 (4th Cir. 1987), cert. denied sub nom. Marcos v. United States, 56 U.S.L.W. 3248 (U.S. Oct. 6, 1987) (No. 87-34). This case concerned a grand jury investigation into possible corruption relating to American companies' arms contracts with the Philippines. Former President Ferdi- 
Second and Fourth Circuits have suggested that the policy favoring immunity for heads of state-avoidance of embarrassment of the Executive in conducting foreign policy-does not carry the same weight in cases of individuals no longer acting in their official capacities. ${ }^{21}$ Taking a radically different tack, the Ninth Circuit has relied on the act of state doctrine, not immunity, to bar a suit against ex-Philippine President Ferdinand Marcos that alleged conversion of government funds and property. ${ }^{22}$

This confusion among the circuits demonstrates that American courts have not yet fully come to terms with a new type of international behavior. While outside powers have long assisted the departure of disfavored leaders, it has only been within the last decade that home countries and

nand Marcos and his wife argued that head of state immunity shielded them from compulsory process requiring production of documents. The Fourth Circuit ruled that it must respect the new Philippine government's waiver of any immunity the Marcoses might still possess, reasoning that principles of international comity suggest that immunity is not personal to the holder, but "is primarily an attribute of state sovereignty." Id. at 1111. The court analogized the Marcoses' status to that of diplomats, whose immunity exists only at the pleasure of their states. Id. While the Fourth Circuit assumed arguendo that ex-heads of state might enjoy immunity, one is left to wonder how such a result might obtain if, as the court concludes, immunity is inextricably linked with sovereignty and is never a private individual right.

In its brief opposing appellants' petition for certiorari-the first public expression ever of the U.S. government's position on ex-head of state immunity - the United States first argued that a foreign sovereign's power to waive diplomatic immunity and sovereign immunity implies a similar power to waive immunity for ex-heads of state. Brief for the United States in Opposition at 5-8, Marcos v. United States, cert. denied, 56 U.S.L.W. 3237 (U.S. Oct. 6, 1987) (No. 87-34) [hereinafter Marcos Brief] (opposing grant of writ of certiorari). This reasoning by analogy, however, ignores policy arguments favoring special treatment for ex-heads of state. See infra Section II-B. The government also argued that appellants would have the Court confer immunity on Marcos that would be far broader than that available to the President of the United States; therefore, the government argued, appellants' claims were facially unreasonable. Marcos Brief, supra, at 8. This analysis, however, ignores the unique historical underpinnings on which the Court has built presidential immunity doctrine. See Nixon v. Fitzgerald, 457 U.S. 731 (1982). Indeed, the government did not cite direct support for any of these assertions.

21. The Second Circuit upheld a preliminary injurction granted to the Republic of the Philippines prohibiting the sale or transfer of New York real property allegedly owned by ex-President Ferdinand Marcos and Imelda Marcos. The court refused to read current head of state doctrine to protect defendants:

[W] are not at all certain that the immunity of a foreign state . . . goes so far as to render a former head of state immune as regards his private acts. . . . The rationale underlying sovereign immunity-avoiding embarrassment to our government and showing respect for a foreign state-may well be absent when the individual is no longer head of state and the current government is suing him.

Republic of the Phil. v. Marcos, 806 F.2d 344, 360 (2d Cir. 1986) (citation omitted).

Similarly, the Fourth Circuit recognized the potential political costs of granting immunity to exPresident Marcos, particularly in a suit where the successor government was the plaintiff. United States v. (Under Seal) (In re Grand Jury Proceedings: John Doe No. 700), 817 F.2d 1108, 1111 (4th Cir. 1987), cert. denied sub nom. Marcos v. United States, 56 U.S.L.W. 3237 (U.S. Oct. 6, 1987) (No. 87-34).

22. Republic of the Phil. v. Marcos, 818 F.2d 1473 (9th Cir. 1987). The successor Philippine government brought suit against Ferdinand and Imelda Marcos under the civil provisions of the Racketeer Influenced and Corrupt Organizations Act, 18 U.S.C. §§ 1961-1968 (1982), charging the Marcoses with operating the Philippine government as a criminal enterprise and embezzling national wealth. The Ninth Circuit vacated a preliminary injunction against the Marcoses preventing the transfer of property held by, or on behalf of, them anywhere in the world. The court did not reach the question of immunity but reasoned that the act of state doctrine, see infra note 83 , prevented adjudication of the official acts of a government then recognized by the United States. 818 F.2d at 1481-88. 
their nationals have pursued ex-leaders in American courts. ${ }^{23}$ Recent examples are a case involving the former Shah of Iran, ${ }^{24}$ and the torrent of litigation against Ferdinand Marcos. ${ }^{25}$ Historically, foreign states and individual victims either did not turn to the judicial process at all, or sought extradition. ${ }^{28}$ Now, however, future foreign leaders who seek to escape political turmoil by coming to the United States must risk facing their pursuers in court. ${ }^{27}$

23. For a brief discussion of the genesis of this trend, see infra notes 26-27. The practice of pursuing former leaders in American courts to extract civil remedies is, of course, fundamentally different from seeking extradition of fugitive leaders to face criminal prosecution in their home countries. The terms of extradition are articulated in the many bilateral treaties the United States has concluded with countries around the world. For a discussion of the current state of the American law of extradition, see ThiRd Restatement, supra note 3, \$§ 476-479; see also Jimenez v. Aristeguieta, 311 F.2d 547 (5th Cir. 1962), cert. denied sub nom. Jimenez v. Hixon, 373 U.S. 914 (1963).

24. Islamic Republic of Iran v. Pahlavi, 467 N.E.2d 245 (N.Y. 1984) (suit by successor government against former Shah seeking recovery of allegedly misappropriated funds; dismissed on forum non conveniens grounds).

25. Republic of the Phil. v. Marcos, 818 F.2d 1473 (9th Cir. 1987) (suit to recover or freeze assets allegedly improperly possessed or controlled by the Marcoses; dismissed under act of state doctrine); United States v. (Under Seal) (In re Grand Jury Proceedings: John Doe No. 700), 817 F.2d 1108 (4th Cir. 1987) (grand jury investigation into possible corruption concerning U.S. arms contracts with the Philippines), cert. denied sub nom. Marcos v. United States, 56 U.S.L.W. 3237 (U.S. Oct. 6, 1987) (No. 87-34); Domingo v. Marcos, No. G82-1055 V, slip op. (W.D. Wash. Dec. 23, 1982) (suit for damages against President Marcos dismissed following suggestion of immunity), modified, Estate of Domingo v. Republic of the Phil., 808 F.2d 1349 (9th Cir. 1987) (appeals court refused to review district court ruling that Marcos may not plead head of state immunity as a shield against taking deposition; motion pending on whether Marocs can be reinstated as defendant under FED. $R$. CIv. P. 54(b) on grounds that 1982 dismissal was never reduced to judgment); Republic of the Phil. v. Marcos, 806 F.2d. 344 (2d Cir. 1986) (suit to take possession of property allegedly acquired with government funds); Azurin v. Von Raab, 803 F.2d 993 (9th Cir. 1986) (mandamus seeking release of goods held by Customs Service not available), cert. denied, 107 S. Ct. 3264 (1987); Republic of the Phil. v. Marcos, Nos. 86-0123 \& 86-0155, slip op. (D. Haw. Mar. 21, 1986) (action by Philippine government to recover property detained by U.S. Customs Service upon Marcos' entry into Hawaii; Marcos counterclaimed that Philippine and U.S. governments were conspiring to deprive Marcos of international right to travel); Republic of the Phil. v. Marcos, No. 86-146, slip op. (N.D. Cal. Feb. 11, 1987) (Marcos served subpoena on Solicitor General of Philippines; court held head of state immunity did not reach Solicitor General of Philippines, but quashed subpoena on finding of inartful grant of diplomatic immunity).

A number of plaintiffs have brought suit under the Alien Tort Statute, 28 U.S.C. $\$ 1350$ (1982), charging Marcos with violating their internationally recognized human rights while acting under color of state law. Ortigas v. Marcos, No. C 86-0975 SW (N.D. Cal. Jan. 22, 1987); Sison v. Marcos, No. 86-0225 (D. Haw. July 18, 1986); Hilao v. Marcos, No. 86-390 (D. Haw. Jul. 18, 1986); Trajano v. Marcos, No. 86-0207 (D. Haw. Jul. 18, 1986). Claims based on alleged human rights violations would not be barred under this Note's proposal. See infra notes 85-97 and accompanying text.

26. In this century fugitive political leaders generally have been protected from suit in the refuge state. For example, following World War I, the Netherlands refused the Allies' request either to surrender the Kaiser, whom the Dutch Government had accepted as a political refugee, or to try Wilhelm in Dutch courts. See J. Willis, Prologue to Nuremberg: The Politics and Diplomacy of Punishing War Criminals of the First World War 98-112 (1982). Throughout much of this century, fugitive leaders in Latin America were virtually never extradited, and there is no record of their being prosecuted in the sanctuary country. See Kirchheimer, Asylum, 53 AM. PoL. Sci. Rev. 985, 1001-05 (1959). See generally Latin American Radicalism (I. Horowitz, J. De Castro \& J. Gerassi eds. 1969) (outlining the factors underlying Latin American asylum practices).

27. In general, domestic courts are becoming fora for what one scholar has called "transnational public law litigation." Koh, Civil Remedies For Uncivil Wrongs: Combatting Terrorism Through Transnational Public Law Litigation, 22 TEx. INT'L L.J. 169 (1987). In transnational public law litigation, plaintiffs turn to domestic courts to enunciate principles and norms of public international law, particularly relating to human rights and the extent of state and individual responsiblity for 
This new trend of aggressive transnational ${ }^{28}$ litigation against ex-heads of state may in some cases disrupt the Executive's ability to help effect transitions of power abroad. ${ }^{29}$ Such transitions might be delayed or defeated if a head of state chooses to remain in power rather than face the possibility of extensive litigation in American courts. An offer of immunity might be a useful political lever to speed the departure of disfavored leaders-to be extended when such departure is deemed to serve the national interest of the United States. ${ }^{30}$

\section{Proposed Expansion}

This Note seeks to supplant the current confusion with a structured immunity doctrine, designed to exploit ex-head of state's immunity's utility as a political tool and grounded in clear legal principles. A proper analysis of ex-head of state immunity must balance the values alternatively served and sacrificed by offering former leaders a shield against litigation. On one hand, a grant of immunity would deprive society of the values advanced by the process of adjudication: the enunciation of moral norms (regarding the appropriate relationship between a head of state and the governed), ${ }^{31}$ the deterrence of deviant activity and encouragement of

securing those rights. This new phenomenon may have arisen from the confluence of two powerful trends: the use of domestic courts as a means for social change on a domestic level, see Chayes, The Role of the Judge in Public Law Litigation, 89 HARv. L. REv. 1281 (1976), and "declining faith in international adjudication as a meaningful process for enunciating international norms or curbing national misconduct," Koh, supra, at 201. For a general discussion of transnational public law litigation and its genesis, see Koh, supra, at 199-201 \& nn.103-10.

28. Of course, civil litigation against ex-heads of state need not be transnational in order to be disruptive. Potential plaintiffs might not be of the same nationality as the ex-head of state and could even be U.S. citizens. In order to be effective, immunity would obviously have to extend to these categories of plaintiffs as well. This Note frames its analysis with reference to transnational litigation only because many recent suits against former leaders are of that character. See supra note 25 .

29. See infra notes 39-52 and accompanying text (discussing the President's general role in conducting foreign policy and the appropriateness of conferring upon the Executive discretion to offer immunity.)

30. The term "national interest" obviously cannot be defined with great precision. It is used here simply to convey the notion that the interests of particular individuals must often give way to the perceived interests of larger political units. The Supreme Court has adverted to this principle, for example, in cases in which the Executive has suspended or extinguished the claims of individual plaintiffs in order to advance U.S. foreign policy interests. See, e.g., Dames \& Moore v. Regan, 453 U.S. 654 (1981); United States v. Pink, 315 U.S. 203 (19.42); United States v. Belmont, 301 U.S. 324 (1937).

This Note rests on the assumption that peaceful transitions of power are generally more advantageous to U.S. interests than more turbulent changes in government. See N.Y. Times, Feb. 25, 1986, at A30, col. 1 (editorial urging peaceful departure of Philippine President Ferdinand Marcos and installation of successor Corazon Aquino). However, the Executive, see infra notes 39-52, must make the appropriate political calculations. The President must first decide whether a peaceful transition is desirable, and then whether an offer of immunity would serve that end.

31. See Fiss, Against Settlement, 93 YALE L.J. 1073, 1078-79 (1984) (arguing for use of public law litigation to keep government officials in check); see also Michelman, The Supreme Court and Litigation Access Fees: The Right to Protect One's Rights, 1973 Duke L.J. 1153, 1175-77; Chayes, The Role of the Judge in Public Law Litigation, 89 HARv. L. REv. 1281 (1976). In domestic public law litigation, as Professor Chayes describes it, private claimants use the judicial process for the enunciation of moral norms. This proposal for limiting former leaders' exposure to suit comes at a time when courts are beginning to enunciate norms of individual and state responsiblity. See Koh, supra 
individual behavior "in ways thought socially desirable," and the compensation of victims. ${ }^{32}$ A grant of immunity might incur the hostility of the successor government and deny the latter and others an opportunity to recover possibly ill-gotten gains. ${ }^{33}$ Nonetheless, the option of immunity could help the Executive influence political change in countries vital to American security interests and might alter the political calculus of an embattled foreign leader, perhaps moving him to a swifter, less violent exit. ${ }^{34}$ Deprivation of particular claims of right ${ }^{35}$ may be necessary to provide a tool for inducing the swift departure of foreign leaders. ${ }^{36}$

note 27; see also Sohn, The New International Law: Protection of the Rights of Individuals Rather than States, 32 AM. U.L. Rev. 1 (1982); THIRD RestaTEMENT, supra note 3, pt. VII. Foreclosure of suits against ex-heads of state undoubtedly hinders the development of a transnational companion to traditional domestic public law litigation, albeit for a limited range of cases.

32. See Michelman, supra note 31,1172-77. For a discussion of the benefits of adjudication as a mechanism of dispute resolution for private parties, see Fuller, The Forms and Limits of Adjudication, 92 Harv. L. Rev. 353 (1978).

33. The interests of both Americans and foreign nationals might be adversely affected by an offer of immunity to a foreign head of state if, for example, the successor government were denied access to American courts and then retaliated against U.S. plaintiffs seeking access to the sovereign's courts.

34. Admittedly, it is an open question whether a leader's fear of transnational litigation would deter his departure. The track record of transnational litigation is not long enough to allow a definitive assessment of its effect on a leader's political calculations. However, even if the causal connection between the threat of litigation and a leader's inclination to remain in power is speculative, it is at least plausible that a head of state might factor an offer of immunity into his calculus. This Note argues that the President should be endowed with a potentially useful political tool.

35. Like diplomatic and sovereign immunity, a grant of ex-head of state immunity need not run afoul of the takings clause, U.S. CoNST. amend. V. Even though the granting of diplomatic immunity may effectively constitute a taking of a private litigant's property interest, no court has allowed compensation under the takings clause. See L. Henkin, Foreign Afrairs and the Constitumion, 264-65 (1972). Until the enactment of the FSIA, courts gave similar effect to executive suggestion of sovereign immunity and did not allow compensation. See supra notes 4-8 and accompanying text.

Admittedly, this expansion of immunity doctrine comes at a time when courts are expanding the meaning of "taking" and are holding out the possibility of recovery in areas heretofore foreclosed. See, e.g., Dames \& Moore v. Regan, 453 U.S. 654 (1981) (reserving question of takings claim against United States in Court of Claims); Ramirez de Arellano v. Weinberger, 724 F.2d 143 (D.C. Cir. 1983), rev'd, 745 F.2d 1500 (D.C. Cir. 1984) (en banc), vacated, 471 U.S. 1113 (1985) (challenging occupation of plaintiffs' Honduran land for use as military training facility). See generally L. HENKIN, supra, at 259-66 (detailing judicial gloss on takings clause). For a critical assessment of the Court's decision in Dames \& Moore to allow a takings claim, see Trimble, Foreign Policy Frustrated-Dames \& Moore, Claims Court Jurisdiction and a New Raid on the Treasury, 84 Colum. L. REv. 317, 319 (1984).

36. Some might argue that it is not the place of the United States to become a haven for former foreign leaders. This Note does not argue that the executive branch must offer immunity to any foreign leader requesting it. Rather, a doctrine of ex-head of state immunity provides the President with another option for his foreign policy. It relies on the executive branch's expertise in foreign affairs to determine when employment of the doctrine would be beneficial. Many other options are still available, ranging from denial of the foreign leader's request to assisting the leader's departure to a third country.

Furthermore, it may seem counterintuitive to argue for expanding current immunity doctrine at a time when Congress, in passing the FSIA, has eliminated presidential freedom to confer sovereign immunity and has narrowed the scope of immunity for sovereign states. However, ex-head of state immunity has a utility not shared by the doctrine of foreign sovereign immunity. Sovereign immunity cannot be used to hasten the exit of embattled leaders because the FSIA targets state activity, not that of particular individuals. 


\section{The Power to Grant Immunity: Legal and Political FACTORS}

This Section evaluates, first, whether the Constitution designates any single institution within the federal government as the proper repository of the power to grant immunity. A legal analysis of the constitutional allocation of power to offer immunity to ex-heads of state suggests that the executive and legislative branches share overlapping zones of competence in several areas where this new doctrine might be applied. Second, a policy analysis suggests that a statutory framework would be the best means to enable the President to employ the doctrine effectively.

\section{A. Institutional Competence to Offer Immunity to Former Heads of State}

While the authority to confer immunity on former heads of state is undoubtedly a federal power, ${ }^{37}$ textual commitments and historical practice indicate that each of the three branches can lay some claim to the power to grant immunity. ${ }^{38}$

\section{Presidential Qualifications}

The Constitution and historical practice vest in the President a range of foreign policy powers, many of which are implicated in the power to confer immunity on ex-heads of state.

Since it might be tied to American efforts to effect a peaceful political

37. The states of the Union are generally circumscribed from interfering with the conduct of foreign policy. See Zschernig v. Miller, 389 U.S. 429 (1968). As a dactrine, ex-head of state immunity implicates a number of constitutional powers historically within the exclusive province of the national government. See L. HENKIN, supra note 35, at 227-48.

38. This Note's analysis of the respective constitutional competence of Congress and the Executive is guided by Justice Jackson's concurring opinion in Youngstown Sheet \& Tube Co. v. Sawyer, 343 U.S. 579, 634 (1952). In Youngstown, the Court rejected the legality of President Truman's order to seize the steel mills during a labor dispute absent congressional authorization. Justice Jackson delineated three categories of presidential action, each describing a different constitutional basis from which the Executive draws authority to act:

1. When the President acts pursuant to an express or implied authorization of Congress, his authority is at its maximum, for it includes all that he possesses in his own right plus all that Congress can delegate. ...

2. When the President acts in absence of either a congressional grant or denial of authority, he can only rely upon his own independent powers, but there is a zone of twilight in which he and Congress may have concurrent authority, or in which its distribution is uncertain. . . .

3. When the President takes measures incompatible with the expressed or implied will of Congress, his power is at its lowest ebb, for then he can rely only upon his own constitutional powers minus any constitutional powers of Congress over the matter. Courts can sustain exclusive presidential control in such a case only by disabling the Congress from acting upon the subject. Presidential claim to a power at once so conclusive and preclusive must be scrutinized with caution, for what is at stake is the equilibrium established by our constitutional system. 343 U.S. at 635-38 (Jackson, J., concurring) (citations omitted).

This Note examines constitutional provisions implicating the responsibilities of the Legislature and the Executive in shaping ex-head of state immunity. It suggests that a statutory framework is the best means of structuring the doctrine because it would place presidential action in Jackson's first category and thus on the firmest constitutional ground. See infro notes 72-79 and accompanying text. 
transition in a foreign state, an offer of immunity may draw on the power to recognize new foreign governments, which is exclusively within the President's constitutional competence. ${ }^{39}$ In two landmark cases, United States $v$. Pink ${ }^{40}$ and United States $v$. Belmont, ${ }^{41}$ the Court upheld an independent executive agreement that effectively settled private litigants' claims against the new Soviet government as a constitutional emanation of the President's recognition power. The claims had stood in the way of establishing normal relations between the two governments. ${ }^{42}$

In addition to this textual commitment, ${ }^{43}$ the courts have also recognized the President's general or "plenary" power to conduct foreign affairs, which is not drawn from specific language in the Constitution, but from the spirit of Article II as illustrated by recurrent presidential practice. ${ }^{44}$ In United States v. Curtiss-Wright Export Corp., ${ }^{45}$ Justice Suther-

39. "Recognition is indisputably the President's sole responsibility, and for many it is an 'enumerated' power implied in the President's express powers to appoint and receive Ambassadors." L. HENkIN, supra note 35 , at 178 (citation omitted); U.S. CoNST. art. II, $\S 3$.

40. 315 U.S. 203 (1942)

41. 301 U.S. 324 (1937).

42. In Belmont, Justice Sutherland, speaking for the Court, said:

The recognition, establishment of diplomatic relations, the assignment and agreements with respect thereto, were all parts of one transaction, resulting in an international compact between the two governments. That the negotiations, acceptance of the assignment [of claims from the Russian to the American government, depriving mostly foreign claimants of recovery] and agreements and understandings in respect thereof were within the competence of the President may not be doubted. . . . [T] Exe Executive had authority to speak as the sole organ of [the national] government.

301 U.S. at 330.

Pink suggests that presidential actions designed to remove obtacles in the way of recognition would be entilled to considerable deference in the courts. "It was the judgment of the political department that full recognition ... required the settlement of all outstanding [claims]. . . . We would usurp the executive function if we held that that decision was not final and conclusive in the courts." Pink, 315 U.S. at 230.

In light of the Court's broad reading of the recognition power, the President undoubtedly could rely on his inherent power to confer immunity on heads of state in connection with his recognition of a foreign state's government. Justice Brennan's dissent in Goldwater v. Carter argues that the President's inherent power also extends to de-recognition of an existing government and recognition of a new one. "Abrogation of the defense treaty with Taiwan was a necessary incident to Executive recognition of the Peking Government ... . Our cases firmly establish that the Constitution commits to the President alone the power to recognize, and withdraw recognition from, foreign regimes." Goldwater v. Garter, 444 U.S. 996, 1007 (1979) (Brennan, J., dissenting) (Senator's challenge to President's abrogation of Taiwan defense treaty; judgment below vacated with instructions to dismiss complaint). This reasoning suggests that the President could rely on his inherent power to confer immunity on an ex-head of state in connection with de-recognition of an existing regime and recognition of a new government. See infra note 61 and accompanying text.

43. Another textual grant to the President, the power to grant pardons, would seem to provide additional support for executive authority to confer ex-head of state immunity. Under Article II, the Executive has the unilateral "Power to grant Reprieves and Pardons for Offences against the United States, except in Cases of Impeachment." U.S. CoNST. art. II, § 2. However, this power has been interpreted to extend only to criminal cases involving American law; thus, the President's Article II power to pardon would not permit him to grant immunity in civil cases between private parties. W.H. Humbert, The Pardoning Power of the President 54 (1941) ("In such civil cases only the rights and interests of individuals are involved. This being true, there is nothing concerning the government which the pardoning power can release or acquit."); see also United States v. Wilson, 32 U.S. (7 Pet.) 150, 160 (1833) (Marshall, C.J.) ("A pardon . . . exempts the individual . . . from the punishment the law inflicts for a crime he has committed.").

44. See L. Henkin, supra note 35, at 50. 
land recognized the supreme power of the federal government to conduct foreign affairs. ${ }^{4}$ Courts $^{47}$ and commentators ${ }^{48}$ have located much of this "plenary" power in the executive branch. This plenary power is limited by constitutional commitments to Congress. ${ }^{48}$ Nonetheless, courts have given considerable deference to presidential discretion in a wide range of foreign affairs matters, ${ }^{80}$ and arguably the power to grant immunity to foreign heads of state is within the President's authority to set foreign policy. Indeed, prior to enactment of the FSIA, courts gave dispositive effect to the President's suggestion of immunity for foreign sovereigns, ${ }^{\text {,1 }}$ and they continue to defer to the Executive in cases involving heads of state. $^{.52}$

\section{Congressional Competence}

An offer of immunity to an ex-head of state seeking entry into the United States is related to the power of Congress to legislate in the area of immigration. The Supreme Court has held this power to be broad and entitled to considerable deference by the courts. ${ }^{.3}$

In enacting the FSIA, Congress relied partly on the law of nations clause $^{84}$ as a source of power in regulating the immunity of foreign sovereign states. ${ }^{\mathrm{bS}}$ Congress could rely on this clause in structuring the immu-

45. 299 U.S. 304 (1936).

46. Id. at 315-16; see L. HeNkIN, supra note 35, at 39 (summarizing majority opinion).

47. Chief Justice Marshall's famous statement that "[t] ]he President is the sole organ of the nation in its external relations, and its sole representative with foreign nations," 6 ANNALS OF CoNG. 613 $(1800)$, often has been cited by courts to justify exercise of presidential power. See, e.g., CurtissWright, 301 U.S. at 319.

48. See L. Henkin, supra note 35, at 45-50 (discussing range of actions the President has undertaken to conduct foreign policy without evidence of clear textual basis); see also E. CoRwIN, THE President: Office and Powers 1787-1957, at 177-84 (1957); W. Wilson, Constitutional Government in THE United States 77 (1921) ("One of the greatest of the President's powers is . . . his control, which is very absolute, of the foreign relations of the nation.").

49. See infra notes 53-59 and accompanying text; see also L. HENKIN, supra note 35, at 50 ("[The President's] powers are limited, of course, by implications in grants to Congress . . . .").

50. See, e.g., Dames \& Moore v. Regan, 453 U.S. 654 (1981) (President has plenary authority, implicated by congressional acquiescence, to settle claims of American litigants against foreign governmental entities); Chicago \& Southern Air Lines v. Waterman Steamship Corp., 333 U.S. 103 (1948) (presidential discretion to grant or deny applications regarding foreign air transportation not subject to judicial review).

51. See Ex parte Peru, 318 U.S. 578 (1943); see also Republic of Mex. v. Hoffman, 324 U.S. 30 (1945); Compania Espanola v. Navemar, 303 U.S. 68 (1938).

52. See supra note 10 .

53. In the Chinese Exclusion Case, the Court held that Congress' power to control immigration, albeit unenumerated, inhered in the sovereignty of the United States. This power has never been challenged. See The Chinese Exclusion Case, 130 U.S. 581 (1889); see also Henkin, The Constitution and United States Sovereignty: A Century of Chinese Exclusion and Its Progeny, 100 Harv. L. Rev. 853,859 (1987) ("[The Court's opinion has] been taken to mean that there are no constitutional limitations on the power of Congress to regulate immigration. Congress can determine whether to admit aliens, how many to admit, and whom to admit.").

54. U.S. ConST. art. I, $\S 8$, cl. 10 ("The Congress shall have Power . . . To define and punish Piracies and Felonies committed on the high Seas, and Offenses against the Law of Nations").

55. "Constitutional authority for enacting [the Foreign Sovereign Immunities Act] derives from the constitutional power of the Congress to prescribe the jurisdiction of Federal courts . . . to define 
nity of former heads of states, as well. Congress arguably may limit the extent to which ex-head of state immunity might be used as a shield against claims based on other statutes enacted under this clause, such as the Alien Tort Statute. ${ }^{58}$

The Court has also held that Congress possesses a general unenumerated power to legislate with respect to foreign affairs ${ }^{57}$ - "the legislative derivative of the powers of the United States inherent in its sovereignty." Concomitant with this undefined power are general powers without which the conduct of foreign policy would be impossible-the taxing and spending clause, the foreign commerce clause, and the necessary and proper clause. These undefined plenary powers might be implicated in offering immunity to a foreign leader seeking entry to the United States.

Finally, Congress has the power to regulate the jurisdiction of federal courts. ${ }^{68}$ It relied on that authority in enacting the FSIA, ${ }^{80}$ and Congress could rely on that same power when enacting an immunity statute for former heads of state.

This review of the powers entrusted to the political branches suggests that the power to grant immunity, while possibly within the President's sole province in some circumstances, implicates legislative and executive areas of competence. The policy analysis in Section II-B argues that a statutory framework is the best means for transferring to the President discretionary authority to confer immunity, while giving Congress a role in delimiting that power. ${ }^{.1}$

\section{Judicial Competence}

While courts might create and apply ex-head of state immunity, ${ }^{62}$ such action in a case implicating foreign affairs would run counter to historical

offenses against the "Law of Nations"' as well as the foreign commerce clause and the necessary and proper clause. HouSE REPORT, supra note 5, at 6611 (emphasis added).

56. 28 U.S.C. $\S 1350$ (1982).

57. Perez v. Brownell, 356 U.S. 44, 57 (1958) (Frankfurter, J.) ("Although there is in the Constitution no specific grant to Congress of power to enact legislation for the effective regulation of foreign affairs, there can be no doubt of this power in the law-making organ of the Nation.") (citing United States v. Curtiss-Wright Export Corp., 299 U.S. 318), overruled on other grounds, Afroyim v. Rusk, 387 U.S. 253 (1967).

58. L. Henkin, supra note 35 , at 68 .

59. U.S. ConsT. art. I, $\S 8$, cl. 9; art. III, $\S 1$.

60. See supra note 55 .

61. The determination of exclusive or shared competence will vary over a spectrum of cases, depending upon the extent to which a specific textual grant is implicated. For example, the President's sole power to confer immunity is probably at its height when it is closely tied to recognition of a new government. See supra notes 39-42 and accompanying text. However, claims of exclusive competence would be suspect if immunity were offered after recognition and the foreign leader were already in American jurisdiction. Similarly, Presidential competence may not eclipse congressional power under the law of nations clause. See supra text accompanying notes 54-55.

62. The courts have fashioned immunities for domestic officials. See Nixon v. Fitzgerald, 457 U.S. 731 (1982) (President has absolute immunity from civil damages for official acts); Harlow v. Fitzgerald, 457 U.S. 800 (1982) (qualified immunity for the President's advisors under an objective good faith standard). 
practice. Prior to the enactment of the FSIA, courts either granted foreign sovereigns absolute immunity or deferred to State Department suggestions; traditional head of state immunity is still conferred pursuant to executive suggestion. ${ }^{63}$ Thus, while courts are not explicitly precluded from fashioning ex-head of state immunity doctrine, past practice indicates general deference to the political branches of government.

\section{B. Policy Considerations Favoring a Statutory Framework}

In light of the foregoing analysis of institutional zones of competence, this Section considers three possible structures for ex-head of state immunity: (1) The courts could create an ex-head of state immunity doctrine and apply it independently; (2) Courts could grant immunity pursuant to suggestion by the executive branch;, ${ }^{64}$ or (3) Congress could formally structure the boundaries of the power to confer immunity, bestowing discretionary authority on the President in a range of circumstances defined by statute. After examining each proposal, this Note concludes that a statutory framework is preferable for three reasons. First, it would maximize the doctrine's usefulness as a political tool and take advantage of the President's expertise in foreign affairs. Second, it would ensure that an offer of immunity would be accorded the greatest possible respect in the courts. Third, it is the only means which enables Congress to delimit the range of presidential authority, thereby preserving its role in shaping policy.

\section{Judicial Discretion}

A rule of judicial discretion would negate the usefulness of the immunity doctrine as a tool for advancing American foreign policy. A foreign leader would never be certain of the weight an executive recommendation of immunity would carry in the courts. ${ }^{65}$ Firm assurances of inviolable immunity are necessary to alter the political calculus of a foreign leader seeking escape. ${ }^{66}$ The judicial branch is ill-suited to be the repository of a discretionary tool of foreign policy. ${ }^{67}$

\footnotetext{
63. See supra note 10 and accompanying text.

64. See infra note 72 .

65. Under this model, courts would be free to disregard executive suggestions.

66. It is possible for courts to provide for swift disposal of suits against former heads of state through motions for summary judgment, thus easing somewhat the potential burdens on ex-heads of state of being subject to suit. But see Nixon, 457 U.S. at 816 \& n.26 (discussing limits of using summary judgment to resolve disputed questions of fact in order to protect qualified immunity of domestic officials). However, even exposing ex-heads of state to the potential of proceeding to the merits is enough to gut the effectiveness of the doctrine, which is premised on the certainty that immunity is inviolable.

67. Courts, though no doubt competent to construct a doctrine of ex-head of state immunity, are not designed to apply it as would a political branch. See generally A. BICKEL, The LEAST DANGERous BRANCH 16-23 (1962) (discussing role of judiciary in democratic process).
} 


\section{Executive Suggestion}

Under a second option, there would be a judicial presumption against immunity, which could be overcome by a suggestion by the State Department that immunity should be granted. ${ }^{68}$ The Third Restatement indicates that the President may suggest immunity for ex-heads of state, though it is not clear that courts would deem the suggestion dispositive. ${ }^{69}$

Two principal factors counsel against use of executive suggestion to provide immunity for former foreign leaders. First, assuming that courts would give executive suggestions dispositive effect, the exercise of such unlimited and undefined authority by the President prevents Congress from shaping the immunity doctrine, in derogation of its textually based authority to participate in the delimitation of the boundaries of this authority. ${ }^{30}$ In addition, immunity conferred pursuant to executive suggestion may lapse when the administration's term ends; claims may be revived under a more favorable administration. ${ }^{71}$ Such a possibility would diminish the value of an American offer of immunity.

\section{Statutory Scheme Allowing Executive Discretion}

An appropriate compromise between unlimited judicial discretion and unlimited executive discretion would be for Congress to pass a statute conferring immunity on ex-heads of state only if the President certifies that subjecting the leader to possible civil suit would be contrary to national interests. ${ }^{72}$ Such a statute would define the types of activities to be pro-

68. In pre-1976 foreign sovereign immunity cases, courts acceded to any executive suggestion, according it dispositive weight without inquiring whether the suggestion was consistent with the restrictive theory of sovereign immunity. See, e,g., Rich v. Naviera Vacuba, 295 F.2d 24 (4th Cir. 1961); see supra notes 4-8 and accompanying text; see also infra note 72.

69. "In the United States, the courts might grant immunity [for ex-heads of state] if suggested by the Executive branch on foreign policy grounds, even though it is not required by international law." ThIRD RESTATEMENT, supra note 3 , § 464 reporters' note 14 (emphasis added).

70. See supra notes 53-59 and accompanying text. The President would be free to suggest immunity in any civil action against an ex-head of state. As Section III of this Note argues, however, there are some acts-violations of human rights-peculiarly within Congress' legislative purview, for which the President should not be allowed to grant immunity. Statutory guidelines are the only way to ensure that the President respect this limitation.

71. It is not clear that principles of issue or claim preclusion would prevent claimants from filing suit following a lifting of immunity, since those doctrines apply to cases that have received a final judgment on the merits. See, e.g., Matthews v. New York Racing Ass'n, 193 F. Supp. 293 (S.D.N.Y. 1961); see also Restatement (SECOND) of Judgments $§ 27$ (1982); Cleary, Res Judicata Reexamined, 57 YALE L.J. 339, 342-45 (1948) (describing policy goals underlying res judicata doctrine). The original grant of immunity might well deter claimants from filing suit in the first instance.

In a statutory immunity scheme, see infra notes 72-79 and accompanying text, Congress could require that an offer of immunity be given permanent effect. Alternatively, Congress might allow the President to lift immunity in rare circumstances, such as if the former leader continued to disrupt his country's internal politics from American shores.

72. The certification procedure could be connected with congressional oversight mechanisms to ensure presidential compliance with the statute's limits. See infra note 77 . The statutory model proposed here is patterned after the so-called Sabbatino Amendment, 22 U.S.C. $\S 2370$ (e)(2) (1982), under which Congress directs the courts not to apply the act of state doctrine to confiscations by foreign states that violate international law, unless the President "determines that application of the 
tected by immunity. ${ }^{73}$ This proposal is attractive for several reasons. First, it places discretion to grant immunity in the branch of the federal government best equipped to manage foreign policy. ${ }^{74}$ Second, foreign leaders can be certain that the President is at the height of his constitutional power because his action derives from a specific congressional delegation. ${ }^{75}$ They thus can be confident that American courts will treat the grant of immunity with great deference. ${ }^{76}$ Finally, reliance on presidential expertise does not require Congress to forfeit control over the substantive content of the doctrine. ${ }^{77}$ Pursuant to its constitutional powers ${ }^{78}$ Congress would retain the discretion to create exceptions to blanket immunity.

A statute would do more than anchor the doctrine in the Constitution: It would reaffirm Congress' constitutionally-assigned role in shaping foreign policy in areas of responsibility shared with the executive branch. While the executive branch has the logistical and structural expertise to determine when the benefits of immunity outweigh its costs, it can lay no preeminent claim to resolve the broader normative questions which precede those determinations: What kinds of leaders do we want to protect from our courts? What values are so dear to us that we do not want them diminished by shielding possible violators from adjudication? The Presi-

act of state doctrine is required in [a] particular case by the foreign policy interests of the United States." Id. While the Sabbatino Amendment has been interpreted narrowly and arguably rendered ineffectual, careful drafting of oversight requirements might avoid that result here.

Congress could create a statute with a presumption opposite to the one suggested here: ex-heads of state would be granted immunity unless the Executive certified otherwise. While this alternative might be workable, it may complicate oversight procedures, since it would require the Executive to inform Congress whenever he decided not to revoke immunity. Furthermore, placing on the President the burden of stating that the ex-head of state should not receive immunity propagates the mistaken notion that ex-heads of state are somehow entitled to their immune status.

73. See infra Section III.

74. The President has at his disposal vast communications and intelligence networks providing both information and analysis. He can best gauge whether a grant of immunity would be useful in effecting a change in government or, alternatively, would provoke too much animosity and opprobrium from the successor government. Recognition of the President's unique competence in foreign affairs is embodied in statutes granting the President wide-ranging powers to act in self-declared emergencies. For an example of this type of statute, see the International Emergency Economic Powers Act, 50 U.S.C. $\$ \S 1701-1706$ (1982 \& Supp. III 1985).

75. See Youngstown Sheet \& Tube Co. v. Sawyer, 343 U.S. 579, 635-37 (1952) (Jackson, J., concurring). Of course, Congress' affirmative delegation would be relevant only in situations where the President could not draw on his sole constitutional authority to offer immunity to an ex-head of state. See supra notes 39-52 and accompanying text.

76. This confidence would not come at the expense of making the judiciary appear to serve as "a mere errand boy for the Executive Branch." First Nat'l City Bank v. Banco Nacional de Cuba, 406 U.S. 759, 773 (1972) (Douglas, J., concurring). For a summary of the argument against executive suggestion as harmful to judicial independence and integrity, see Lowenfeld, supra note 6, at 803-14.

77. Congress may employ several devices to ensure that the President acts within the proposed statute's limits. Congress may enact "sunsetting" legislation which requires the President to seek reauthorization of his delegated authority after a specified period of time. In addition, Congress could enact extensive consultation and reporting requirements, together with strict timetables for fulfilling those requirements.

78. See supra notes $53-60$ and accompanying text. 
dent cannot claim sole competence to answer these kinds of questions in cases where the political branches share competence. ${ }^{79}$

\section{The Need To Limit Ex-Head of State Immunity}

In order to serve American foreign policy interests, ex-head of state immunity should be available only for certain categories of official acts committed by the former leader while in office. ${ }^{80}$ This Section argues that the President should have general discretion to grant immunity to exheads of state for all official acts which do not violate accepted norms of human rights and thus violate international law.

\section{A. Immunity for Legitimate Official Acts}

A former head of state should not be sued in American courts for acts that are associated with implementation of public policy ${ }^{81}$ The immunity doctrine will be effective only if the President can ensure that courts will not inquire into an ex-leader's exercise of a legitimate official function. ${ }^{\mathbf{2 2}}$ Because courts have, in other contexts, abstained from passing on official acts of foreign states conducted in their own territory, the statute should

79. This Note's proposal could easily be incorporated into efforts to amend the FSIA. For a discussion of proposed amendments, see Feldman, Amending the Foreign Sovereign Immunities Act: The ABA Position, 20 INT'L LAw. 1289 (1986).

80. There is no plausible policy argument for offering immunity for acts committed after the leader's departure from office. The rationale behind this immunity doctrine is to offer an enticement to besieged leaders; extension of that offer to acts committed, for example, after the leader's arrival in the United States would be gratuitous.

Furthermore, former heads of state who enter American jurisdiction without the President's invitation or leave their home countries without U.S. assistance or complicity should not be afforded immunity. The grant of immunity is designed as an incentive for effecting a peaceful escape. If such an offer did not enter a leader's calculus, then the U.S. should not reward his escape needlessly. Without this limiting principle, the United States might become the ultimate thieves' haven.

81. For the purposes of this Note, ex-head of state immunity must be considered to extend to all heads of government, heads of state as defined by the constitution-written or unwritten-of the foreign state, and members of their immediate families. See infra note 84 . This definition is narrower than that suggested by international law. See supra note 1. The doctrine's effectiveness as a political tool is contingent on this minimum reach. Congress may choose to extend ex-head of state immunity to foreign ministers as well, but the doctrine's utility is not contingent on that extension; further, Congress understandably may not want to grant the President the broad discretion that inevitably accompanies a broad definition.

82. Courts often analyze the scope of "official activity" in determining whether domestic federal and state officials should enjoy immunity. See Harlow v. Fitzgerald, 457 U.S. 800 (1982); Butz v. Economou, 438 U.S. 478 (1978). However, while in domestic cases courts may employ an objective test to determine whether an individual knew or should have known of the illegality committed in the course of his official activity, such an inquiry here would be an excessive intrusion by the courts into forcign affairs, and U.S. courts would hesitate before embarking on such an exercise. See Banco Nacional de Cuba v. Sabbatino, 376 U.S. 398, 428 (1964). Immunity for actions committed within the scope of official functions is at the core of the proposed doctrine's usefulness as a foreign policy tcol. A bar to judicial inquiry into official actions should pose no obstacle to suits based on human rights violations, because international and American law have identified these acts as beyond the bounds of legitimate governmental discretion. See infra notes 89-93 and accompanying text; see also Letelier v. Chile, 748 F.2d 790, 798 (2d Cir. 1984) (assassination not commercial activity under the FSIA). 
be clearly worded to deter courts from carving out exceptions to immunity for official acts. ${ }^{\text {s }}$

An offer of immunity that covers a leader's official acts may extend to acts which would be considered illegal by American standards, but which, nevertheless, are arguably within a foreign leader's power and not violative of international legal norms. Leaders engaged in activity which might be deemed corrupt by American standards are prime candidates for exhead of state immunity, since immunity would enable the President to help effect the departure of leaders whose practices may impede economic growth or political development. ${ }^{84}$

Immunity for practices which are illegal by American standards-but do not necessarily violate international norms-obviously deprives successor governments of the opportunity to recover ill-gotten gains and may make the United States a target for reprisal. Yet, this is exactly the situation the statute is meant to address. The President will have to weigh the benefits of extricating a corrupt leader from turbulent domestic upheaval against the cost of opprobrium from the successor government and the international community.

\section{B. Human Rights Violations: No Immunity}

Ex-head of state immunity should not extend to leaders whose acts violate international legal norms of human rights. The stigma which would attach to the United States should it provide a safe haven for human rights violators outweighs any benefit derived from encouraging their departure through the offer of immunity ${ }^{85}$ Distinguishing human rights vi-

83. Banco Nacional de Cuba v. Sabbatino, 376 U.S. 398 (1964), set out the modern statement of the act of state doctrine, under which American courts will not sit in judgment over the acts of foreign states occurring in their own territory, even though they may violate international law. Id. at 428 . Courts have relied on State Department suggestions for interpretive assistance, but not dispositive guidance, in ruling on act of state issues. The Department issues a so-called "Bernstein Letter" if it wishes to inform the court that foreign policy considerations do not require the court to refrain from proceeding to the merits. See First Nat'l City Bank v. Banco Nacional de Cuba, 406 U.S. 759 (1972) (plurality relied on Bernstein exception in deciding to take jurisdiction). Courts have created other exceptions to the act of state doctrine. See, e.g., Alfred Dunhill, Inc. v. Republic of Cuba, 425 U.S. 682 (1976) (plurality opinion) (act of state doctrine should not apply with respect to purely commercial obligations); Kalamazoo Spice Extraction Co. v. Provisional Military Gov't of Sacialist Ethiopia, 729 F.2d 422 (6th Cir. 1984) (act of state doctrine will not apply where treaty calls for exercise of jurisdiction).

84. In order to be an effective foreign policy tool, ex-head of state immunity would also have to extend to the former leader's immediate family. This extension of immunity seems consistent with international law. While domestic courts have not ruled on the question of immunity for a head of state's family, they are empowered by statute to grant immunity to diplomats' families. 22 U.S.C. $\$$ 254 (a)-(b) (1982) (codifying Diplomatic Convention, supra note 12). Immunity for diplomatic families is also a principle of customary international law. See THIRD RESTATEMENT, supra note $3, \S 464$ comment a. The Restatement notes that a head of state is "generally given the same personal inviolability and immunities as are accorded to members of special missions, essentially those of an accredited diplomat." Id. $\$ 464$ reporters' note 14 . It thus follows that a head of state's family would also enjoy immunity.

85. Human rights violations and economic abuses are often intertwined. Undoubtedly, ex-heads of state haled into American courts may be accused of a variety of acts, some of which may violate 
olations from other governmental actions reflects post-war trends in customary international law, ${ }^{86}$ multilateral conventions and treaties, ${ }^{87}$ and American jurisprudence, ${ }^{88}$ all of which argue for universal condemnation of these practices and reject policies which lend comfort to perpetrators of these acts.

At least since Nuremburg, ${ }^{89}$ customary international law and international agreements have embodied norms defining minimum prohibitions on domestic governmental actions against individuals and proposing criminal responsibility for violators of these norms. ${ }^{30}$ The Third Restatement of Foreign Relations Law lists internationally recognized protections no government or leader may suspend or deny. ${ }^{\mathbf{9 1}}$ Section 404 recognizes universal jurisdiction for these offenses-any country may punish violators. ${ }^{92} \mathrm{Al}$ -

international norms, some of which may not. While it is desirable that no violator of human rights be able to enjoy a presidential offer of immunity, it is also imperative that plaintiffs not be able to flout an immunity statute by appending a frivolous human rights charge to their complaint. Accordingly, Congress should structure the offer of immunity so that claims of human rights violations would be litigated first; the shield of immunity would be lifted only if litigants were successful on those initial claims. Foreign leaders weighing an offer of immunity would obviously have to consider their exposure to charges of human rights violations.

Since immunity would not be available to leaders who violate human rights, the scope of this Note's proposal is admittedly narrow. While an immunity statute would provide the President with a useful tool, it should not be provided at the expense of other foreign policy goals, such as encouraging adherence to basic principles of legitimate government behavior.

86. See infra note 91 .

87. See infra note 90 .

88. See infra note 91 .

89. The Nuremburg Charter is considered a cornerstone of modern customary international law that protects human rights from state encroachment. See CHARTER of THE INTERNATIONAL MiLITARy Tribunal, Aug. 8, 1945, 59 Stat. 1546, 82 U.N.T.S. 279; ThiRd Restatement, supra note $3, \S 702$ reporters' note 1 .

90. See, e.g., Universal Declaration of Human Rights, G.A. Res. 217, 3 U.N. GAOR I at 71, U.N. Doc. A/810 (1948); Covenant on Givil and Political Rights, G.A. Res. 2200A, 21 U.N. GAOR Supp. (No. 16), at 49, U.N. Doc. A/6316 (1966); Convention on the Prevention and Punishment of the Crime of Genocide, Dec. 9, 1948, __ U.S.T. _ T.I.A.S. No. 1021, 78 U.N.T.S. 277. The United States ratified the Genocide Convention on Feb. 19, 1986. 132 Cong. Rec. S1355 (daily ed. Feb. 19, 1986). See generally M. McDougal, H. Lasswell \& L. Ghen, Human Rights and World Public ORDER (1980) (proposal for human rights framework).

91. There is broad agreement about certain core protections which all human beings enjoy against governmental intrusion. These protections have risen to the level of jus cogens, preemptive rights that no government, especially those with primary prescriptive jurisdiction over a given individual, can deny. "Not all human rights norms are peremptory norms (ius cogens), but those in clauses (a) to (f) of [ $\S 702]$ are, and an international agreement that violates them is void." THIRD RESTATEMENT, supra note $3, \S 702$ comment $n$; see also Lobel, The Limits of Constitutional Power: Conflicts Between Foreign Policy and International Law, 71 VA. L. REv. 1071, 1134-42 (1985).

Section 702 reads:

A state violates international law if, as a matter of state policy, it practices, encourages or condones: (a) genocide, (b) slavery or slave trade, (c) the murder or causing the disappearance of individuals, (d) torture or other cruel, inhuman or degrading treatment or punishment, (e) prolonged arbitrary detention, (f) systematic racial discrimination, or (g) consistent patterns of gross violations of internationally recognized human rights.

Third Restatement, supra note $3, \S 702$.

92. Section 404 reads:

A state has jurisdiction to define and prescribe punishment for certain offenses recognized by the community of nations as of universal concern, such as piracy, slave trade, attacks on or hijacking of aircraft, genocide, war crimes, and perhaps certain acts of terrorism, even where none of the bases of jurisdiction indicated in $\S 402$ is present. 
though current efforts to use the Alien Tort Statute ${ }^{93}$ to seek redress for human rights violations have met with limited success in the courts, ${ }^{94}$ it would be quite a different matter for Congress to affirmatively enact an immunity statute for crimes that are universally condemned.

Some may argue it is morally disingenuous to contemplate immunity for international thieves but not for murderers, as is suggested here. Legal and political considerations, however, suggest that this distinction is indeed valid. First, while commentators have attempted to identify an international consensus on norms regarding government corruption ${ }^{95}$ which might parallel the existing consensus on human rights, global expectations about tolerable standards of bureaucratic efficiency and propriety vary widely. If compelled to adjudicate the issue, American courts might have considerable difficulty identifying objective standards with which to determine whether leaders from other societies knew or should have known that a particular act was not within the scope of their official duties. ${ }^{96}$ In addition, the absence of a universal legal standard regarding economic abuses reflects the fact that such abuses do not elicit the same universal condemnation as do human rights violations. ${ }^{97}$ The benefits derived from permitting courts to inquire into the propriety of possibly illegal economic

ThIRD RestatemENT, supta note $3, \S 404$.

93. 28 U.S.C. $\S 1350$ (1982).

94. See, e.g., Tel-Oren v. Libyan Arab Republic, 726 F.2d 774 (D.C. Cir. 1984), cert. denied, 470 U.S. 1003 (1985) (unanimous dismissal of Alien Tort claim; Judges Bork and Robb relied on broad separation of powers principles in barring review). But see Filartiga v. Pena-Irala, 630 F.2d 876 (2d Cir. 1980) (Alien Tort Statute provides federal jurisdiction for suit by alien against alien defendant accused of deliberate torture perpetrated under color of official authority.).

95. See, e.g., W. M. Reisman, Folded Lies (1979) (discussion of patterns of bribery in national governments and manner in which operational codes diverge from myth systems, or enunciated societal values)

96. The Third Restatement suggests that certain kinds of official acts committed by a foreign leader may fall within the prescriptive and adjudicative jurisdiction of another state. THIRD RESTATEMENT, supra note $3, \S 464$ Reporters' Note 14. To extend American prescriptive and adjudicative jurisdiction beyond violations of international norms would be to hold a former leader liable for acts which may violate American law, but which do not offend any international consensus of behavior. Such an extension is at war with the spirit of the Third Restatement, is an unreasonable and arrogant application of American standards to acts well beyond the United States' borders, and would gut the effectiveness of ex-head of state immunity as a foreign policy tool. While American law establishes clear standards for ethical government conduct, those standards are simply not universally shared. Applying those standards to domestic official acts committed by foreign sovereigns may embarrass our own political branches and excessively intrude into a foreign state's internal affairs. See supra note 22 and accompanying text.

This Note does not rule out the possibility that an international consensus on norms of government conduct will develop and extend to a range of official acts. If customary international law comes to demand more of governments than respecting basic human rights of individuals-that is, if a comprehensive notion of state responsibility to prevent corruption develops and rises to the level of jus cogens - then the distinctions which undergird this Note's analysis would need to be reassessed. A statute providing immunity for ex-heads of state might thus run contrary to international legal principles.

97. See, e.g., Solem v. Helm, 463 U.S. 277, 292-93 (1983) ("[N]on-violent crimes are less serious than crimes marked by violence or the threat of violence."); see also Posner, An Economic Theory of Criminal Law, 85 Colum. L. REv. 1193, 1210 (1985) ("[I]t becomes apparent that even very large financial crimes are less serious than most crimes of violence."). 
activity, even if conducted on a grand scale, are not worth the cost of rendering toothless a potentially useful instrument of foreign policy.

\section{Conclusion}

The proposed doctrine of ex-head of state immunity would be a useful and effective tool of foreign policy. The President could employ it to encourage embattled foreign leaders to leave their home countries swiftly and perhaps more peacefully than they otherwise would. This offer of immunity, while carrying the price of depriving individual plaintiffs of potential compensation, and possibly impeding the enunciation of particular international norms of governmental conduct, is worth its obvious costs if it leads to more peaceful transitions of power in politically unstable societies. At the same time, the doctrine's incarnation in statutory form reaffirms congressional competence to help shape the proper circumstances under which the Executive should exercise his discretion. 